\title{
Development of a coating with UV protection for leather finishing in the automobile industry
}

\section{Desarrollo del recubrimiento para protección a los rayos UV del acabado del cuero para la industria automotriz}

AGUILAR-MARURI，Saul†'，VALENCIA-RODRÍGUEZ，Samantha'，GALINDO-GONZÁLEZ, Rosario" and FUENTES-RAMÍREZ, Rosalba*'

\author{
Universidad de Guanajuato, Division of Natural and Exact Sciences, Department of Chemical Engineering, Noria Alta \\ S/N, Col. Noria Alta, C.P. 36050, Guanajuato, Guanajuato, Mexico. \\ "CONACYT Chair at the Universidad de Guanajuato, Division of Natural and Exact Sciences.
}

ID $1^{\text {st }}$ Author: Saul, Aguilar-Maruri / ORC ID: 0000-0002-1656-472X, CVU CONACYT ID: 955004

ID $1^{\text {st }}$ Coauthor: Samantha, Valencia-Rodríguez / ORC ID: 0000-0002-4188-3028, CVU CONACYT ID: 782949

ID $2^{\text {nd }}$ Coauthor: Rosario, Galindo-González / ORC ID: 0000-0002-3612-1555, CVU CONACYT ID: 223987

ID $3^{\text {rd }}$ Coauthor: Rosalba, Fuentes-Ramírez / ORC ID: 0000-0003-0520-3387, CVU CONACYT ID: 202669

\begin{abstract}
Due to continuous use and environmental factors (humidity and continuous exposure to the sun), the leather upholstery experiences cracking, discoloration and possible yellowing. The above factors significantly decrease the life of leather upholstery in cars. The objective of this work is to synthesize zinc oxide nanoparticles, which have optical properties that allow it to absorb UV radiation and then incorporate them into a polymeric matrix to develop a coating with UV protection for leather finishing in the automobile industry. The particles of zinc oxide were synthesized by the sol-gel method to obtain a nanometric particle size, the method represent a low-cost synthesis method, without the use of surfactants and easily scalable. With monoethylene glycol was formed a stable colloid with the zinc oxide nanoparticles and the polymer matrix. Finally, the final leather finishing obtained for the automotive industry has greater resistance to bending, also thermal stability was improved. In consequence, the lifetime of the leather finishing has improved.
\end{abstract}

UV radiation, Zinc oxide nanoparticles, Leather finishing

\begin{abstract}
Resumen
Debido al uso continuo y los factores ambientales (humedad y exposición continua al sol), la tapicería de cuero experimenta grietas, decoloración y posible amarillamiento. Los factores anteriores disminuyen significativamente la vida útil de la tapicería de cuero en los automóviles. El objetivo de este trabajo es sintetizar nanopartículas de óxido de zinc, que tienen propiedades ópticas que le permiten absorber la radiación UV y luego incorporarlas en una matriz polimérica para desarrollar un recubrimiento con protección UV para el acabado del cuero en la industria automotriz. Las partículas de óxido de zinc se sintetizaron mediante el método sol-gel para obtener un tamaño de partícula nanométrica, este método representa un método de síntesis de bajo costo, sin el uso de tensoactivos y fácilmente escalable. Con monoetilenglicol se formó un coloide estable con las nanopartículas de óxido de zinc y la matriz polimérica. Finalmente, el acabado final del cuero obtenido para la industria automotriz tiene mayor resistencia a la flexión, también se mejoró la estabilidad térmica. En consecuencia, la vida útil del acabado del cuero ha mejorado.
\end{abstract}

Radiación UV, Nanopartículas de óxido de zinc, Acabado de cuero

Citation: AGUILAR-MARURI, Saul, VALENCIA-RODRÍGUEZ, Samantha, GALINDO-GONZÁLEZ, Rosario and FUENTES-RAMÍREZ, Rosalba. Development of a coating with UV protection for leather finishing in the automobile industry. Journal of Scientific and Technical Applications. 2020. 6-17:18-25.

\footnotetext{
* Correspondence to Author (Email: rosalba@ugto.mx)

$\dagger$ Researcher contributing as first author.
} 


\section{Introduction}

Currently, the impact of UV rays in humans has focused on how it causes damage to the structure of collagen, but there are few references of the impact that UV radiation has on leather finishing materials (A. J. Bailey, 1980). In the bibliography, the inclusion of inorganic compounds such as carbon materials and metal oxides to polymeric matrices improves mechanical properties and thermal resistance to leather finishing (Pavel, 2011). Zinc oxide has an excellent absorption of UV radiation material (L. Wallenhorst, 2018), so it is widely used in the manufacture of sunscreens.

The synthesis of metal oxides by the SolGel method implies: simplicity, low cost, reliability, repeatability, relatively simple synthesis conditions (low synthesis temperatures, minimum evaporation loss, minimum contamination), favourable optical properties, higher surface area, greater purity, better microstructural control of metal particles and narrower distributions of particle and pore (J. F. De Lima, 2012).

Many leather finishing use polyurethanes (C. Niculescu, 2012) like film protectors because they have high abrasion resistance, superior hardness, elastomeric properties, good chemical resistance, tensile strength, high extensibility at low temperature and properties that are simple to modify. In this work, a mixture of polyurethane resins and dispersants (provided by leather finishing industry), a polymeric matrix, with inserts of zinc oxide nanoparticles was used as the finishing material and applied by the spray coating technique.

\section{Methodology}

For the synthesis of nanoparticles of $\mathrm{ZnO}$ is necessary a five-step method, as indicated by ( $\mathrm{S}$. Jurablu, 2015) and the modifications made by (Valencia-Rodríguez, 2018).

Solubility and solvent-polymer matrix compatibility tests of the nanoparticles were performed in: 1. Isopropanol, 2. Polyethylene glycol, 3. Ethanol, 4. Ethanol-water mixture (1: 1), 5. Monoethylene glycol, 6. Methanol and 7. EEP (ethyl 3-Ethoxypropionate).
5 layers of the polymer matrix, nanoparticles, and pigment (provided by the company) were applied (by pressure gun), with and without nanoparticles. It was dried in a convective heating oven at $90^{\circ} \mathrm{C}$ for 3 minutes. Previous tests were exposed to solar radiation for 70 days, and it was considered an unexposed reference sample.

All materials were characterized by $\mathrm{X}$ ray diffraction UV-Vis spectroscopy, diffuse reflectance UV-Vis spectroscopy, Scanning electron microscopy (SEM), Raman spectroscopy, Fourier transform IR spectroscopy, Thermogravimetric analysis (TGA) and Chronoamperometry. Evaluation of the colour difference $(\Delta \mathrm{E} *)$, in applied samples to leather finishing, were with a colorimeter.

\section{Results}

The samples were prepared by the sol-gel method using different pH's (Figure 1 and 2) the results confirmed the wurtzite hexagonal phase whose characteristic peaks are located at $32.24^{\circ}$, $34.42^{\circ}, 36.25^{\circ}, 47.54^{\circ}, 56.84^{\circ}, 62.86^{\circ}$ and $68.76^{\circ}$ corresponding to the diffraction planes (100), (002), (101), (102), (110), (103) and (112). With Graphic 1 it follows that the sample analysed has no impurities and small particles have good crystallinity. Graphic 2 also indicates wurtzite phase without impurity residues but the peaks in the diffractogram of the oxide indicates a lower degree of crystallinity. The previous results are due to the $\mathrm{pH}$ of synthesis, 9 and 11 , respectively (L. Li, 2010), (Thambidurai, 2017).

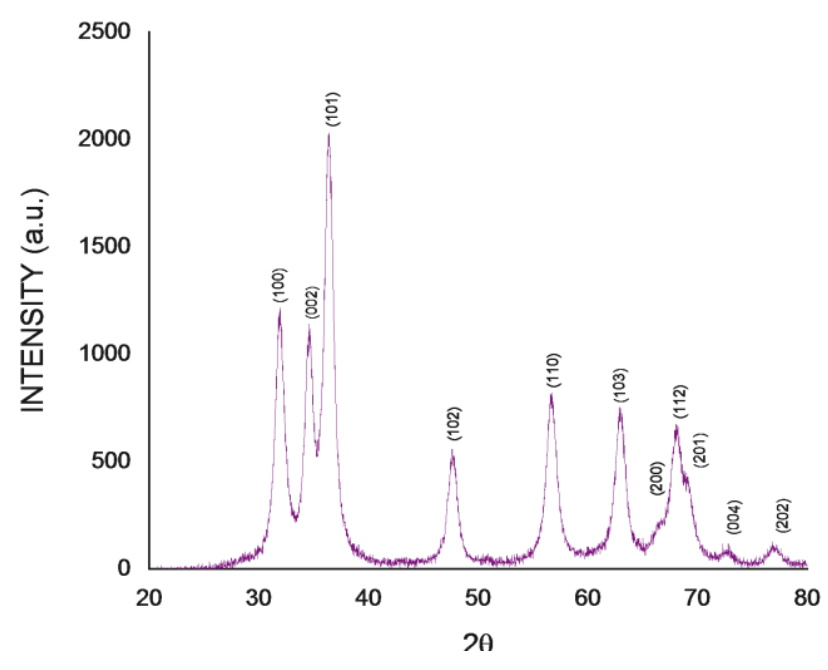

Graphic 1 Diffractogram of $\mathrm{ZnO}$ nanoparticles synthesized via sol-gel at $\mathrm{pH} 9$ Source: own work [OriginPro 9] 


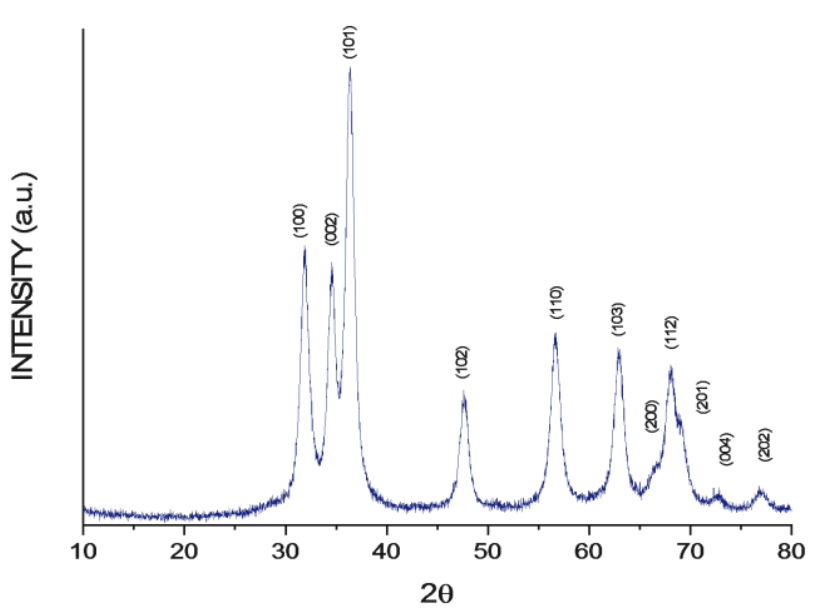

Graphic 2 Diffractogram of $\mathrm{ZnO}$ nanoparticles synthesized via sol-gel at $\mathrm{pH} 11$

Source: own work [OriginPro 9]

Graphic 3 represents the absorption spectra by UV-Vis spectroscopy, with an absorption band at $370 \mathrm{~nm}$. The presence of the highest absorption peak at $355.78 \mathrm{~nm}$ is observed, which confirms the presence of zinc oxide nanoparticles in the solution (Pavel, 2011), (W. A. G. Bruls, 1984). Also, the Graphic 3 corresponds to the $\mathrm{ZnO}$ obtained by method at $\mathrm{pH} 11$, it is observed that the wurtzite phase is also obtained without residues of impurities. The peaks of this diffractogram are less intense, so this material has a lower degree of crystallinity than the previous one (at $\mathrm{pH}$ 9). Direct banned band energy was calculated from the Planck equation (Eq. 1) taking as reference the peak of greatest absorption obtaining $\mathrm{E}_{\mathrm{gap}}=3.49 \mathrm{eV}$.

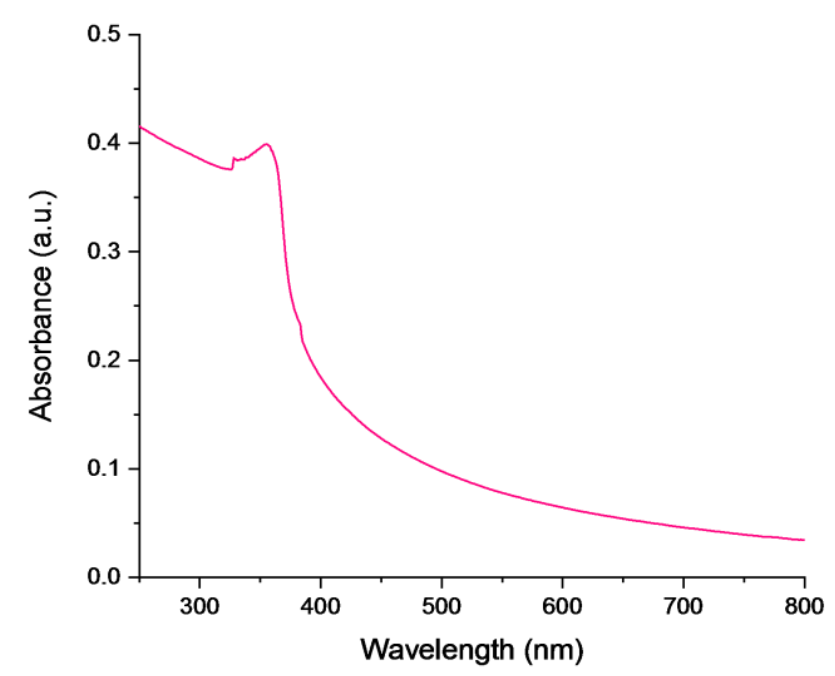

Graphic 3 UV-Vis absorption spectrum of $\mathrm{ZnO}$ nanoparticles

Source: own work [OriginPro 9]

$$
E_{g a p}=h v=\frac{h c}{\lambda}
$$

Where:
- $\mathrm{h}=$ Planck constant $(6.626 \times$ $10^{-34}$ joules).

- $\quad c=$ speed of $\operatorname{light}\left(c=3 \times 10^{8} \mathrm{~m} / \mathrm{s}\right)$.

- $\quad \begin{aligned} & \text { = peak } \\ & \text { wavelength }\end{aligned}\left(3.557836 \times 10^{-7} \mathrm{~m}\right)$.

Considering the diffuse reflectance UVVis spectroscopy, the sample absorption coefficient (at pH 9 and 11) for each wavelength was estimated and it was graphed $(\alpha \hat{K}) 2$ vs $(K v)$ (Graphic 4), for energy estimation forbidden band with Kubelka-Munk model for which $E_{\text {gap }}$ $=3.25 \mathrm{eV}$ was obtained. For both cases, the value is close to that reported in the bibliography for the $\mathrm{ZnO}, \mathrm{E}_{\text {gap }}=3.37 \mathrm{eV}$ (M. Shaban, 2016). Forbidden band energy is influenced by several nanoparticle factors such as morphology, particle size, composition and the presence of defects (oxygen vacancies), (A. K. Zak, 2011).

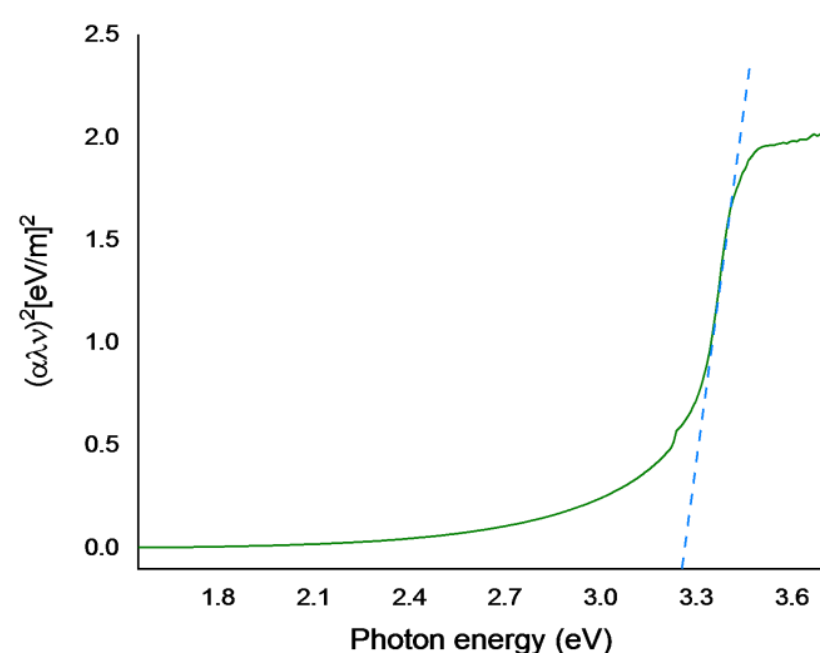

Graphic 4 Kubelka Munk graph of $\mathrm{ZnO}$ synthesized by the sol-gel method at $\mathrm{pH} 9$

Source: own work [OriginPro 9]

Graphic 5 shows that the peak of the highest intensity of the spectrum was located around $438 \mathrm{~cm}^{-1}$ and is due to the $\mathrm{E}_{2}$ (high) mode, which is a typical Raman peak of the wurtzite $\mathrm{ZnO}$ phase (Golzary, 2014). The spectrum shows peaks around $213.12 \mathrm{~cm}^{-1}$, $326.94 \mathrm{~cm}^{-1}, 336.67 \mathrm{~cm}^{-1}, 436.67 \mathrm{~cm}^{-1}, 559.51$ $\mathrm{cm}^{-1}, 583.44 \mathrm{~cm}^{-1}$ which are also attributed to the wurtzite phase. For zinc oxide in the wurtzite phase, 6 first-order vibrational modes are expected, assigned as $\mathrm{A}_{1}, \mathrm{E}_{1}, 2 \mathrm{E}_{2} \mathrm{Y} 2 \mathrm{~B}_{1}$ (C. $\mathrm{A}$. Arguello, 1969). Modes $A_{1}$ and $E_{1}$ are polar and break in optical transverse (TO) and longitudinal optical (LO) phonic modes. The modes $\mathrm{E}_{2}$ $\left(\mathrm{E}_{1}{ }^{\mathrm{LOW}}, \mathrm{E}_{2}{ }^{\mathrm{HIGH}}\right)$ are non-polar and active in the Raman spectrum. 
The band observed around $213.12 \mathrm{~cm}^{-1}$ is attributed to the $\mathrm{E}_{2}{ }^{\mathrm{LOW}}$ mode of the $\mathrm{ZnO}$ in the wurtzite phase. The vibrational modes that appear around $336.67 \mathrm{~cm}^{-1}$ and $436.67 \mathrm{~cm}_{-1}$ in our spectrum are attributed to modes $\mathrm{A}_{1}(\mathrm{TO})$ and $\mathrm{E}_{2}{ }^{\mathrm{HIGH}}$ (associated with oxygen subnet in $\mathrm{ZnO}$ ) of the wurtzite phase. The band that appears in $583 \mathrm{~cm}^{-1}$ is attributed to the $\mathrm{ZnO}$ mode $\mathrm{A}_{1}(\mathrm{LO})$ of the wurtzite phase (al. H. Z., 2002). The peak observed in $326.94 \mathrm{~cm}^{-1}$ is attributed to the second-order Raman process characteristic of the wurtzite phase. The signal marked with an asterisk is attributed to the formation of $\mathrm{ZnO}(\mathrm{OH})_{2}$ (P. Kumar, 2018).

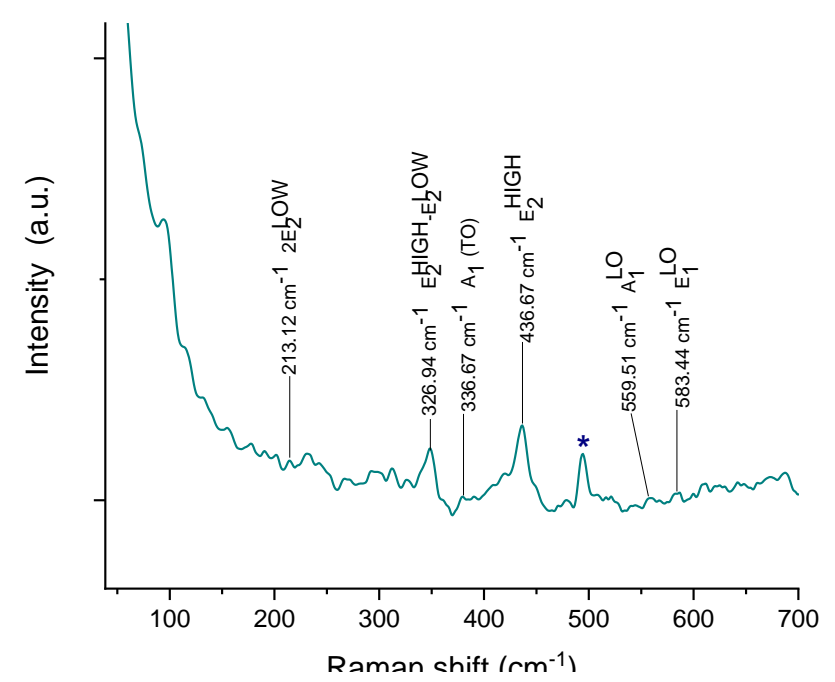

Graphic 5 Raman spectrum of the $\mathrm{ZnO}$ sample synthesized at $\mathrm{pH} 9$

Source: own work [OriginPro 9]

Graphic 6 corresponds to the infrared spectrum of synthesized $\mathrm{ZnO}$, the signal observed in $452 \mathrm{~cm}-1$ is characteristic of the stretching vibrations of the $\mathrm{Zn}-\mathrm{O}$ bond (SotoRobles, 2017), (Prasad, 2018).

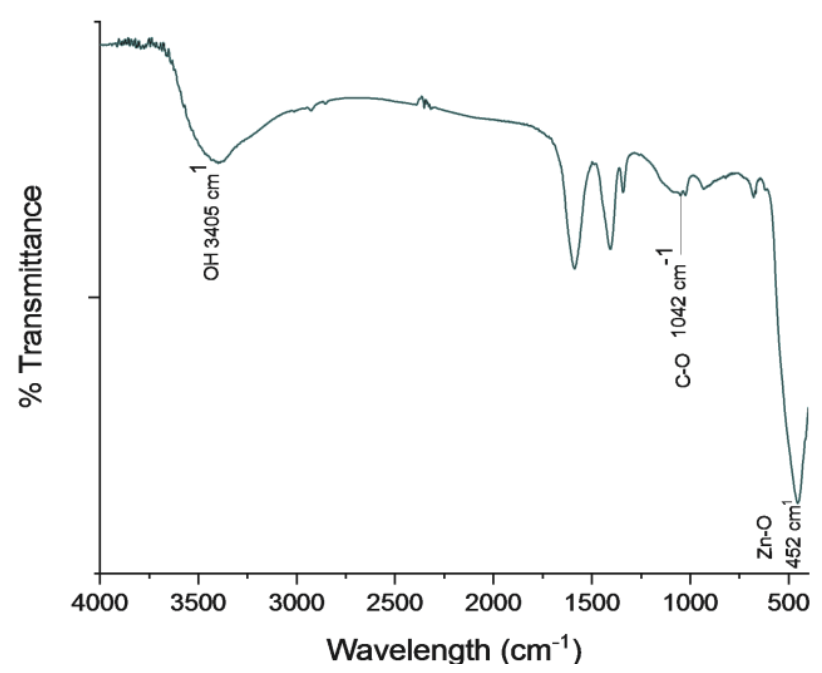

Graphic 6 The infrared spectrum of synthesized $\mathrm{ZnO}$ Source: own work [OriginPro 9]
Graphic 7 shows the TGA results of the $\mathrm{ZnO}$. It can see three stages of weight loss. The total weight loss of $9 \%$ for nanoparticles dried for $2 \mathrm{~h}$ at $60^{\circ} \mathrm{C}$. In the first stage, a small amount of weight loss $(1.5 \%)$ is observed at temperatures below $141^{\circ} \mathrm{C}$, which is considered as the dissociation of weakly bound solvent molecules, such as methanol (D. Sun, 2007). The second stage is between $141^{\circ} \mathrm{C}$ and $386^{\circ} \mathrm{C}$, in which the most significant weight loss is observed, in this range $6.2 \%$ is lost, and this stage is followed by the third stage of weight loss in which a slow weight loss was observed until reaching $9 \%$ of weight lost at $600^{\circ} \mathrm{C}$. The second stage can be attributed to acetate ions which are difficult to remove during washing and to the possible presence in a smaller amount of $\mathrm{Zn}(\mathrm{OH})_{2}$ (al. L. L., 2018).

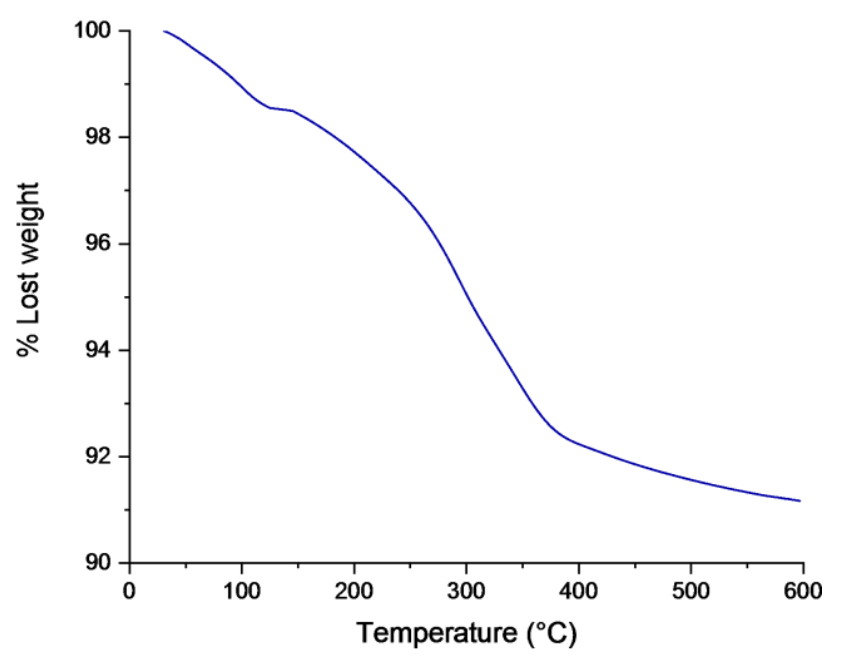

Graphic 7 TGA of ZnO nanoparticles synthesized via solgel

Source: own work [OriginPro 9]

Figure 1 ( $a, b, c$ and d) show that the nanoparticles have a homogeneous and spherical shape. The formation of nanoparticle clusters is observed in better detail in the Figure. In the four micrographs presented, it is observed that the size of the nanoparticles that form the clusters is less than $100 \mathrm{~nm}$. 

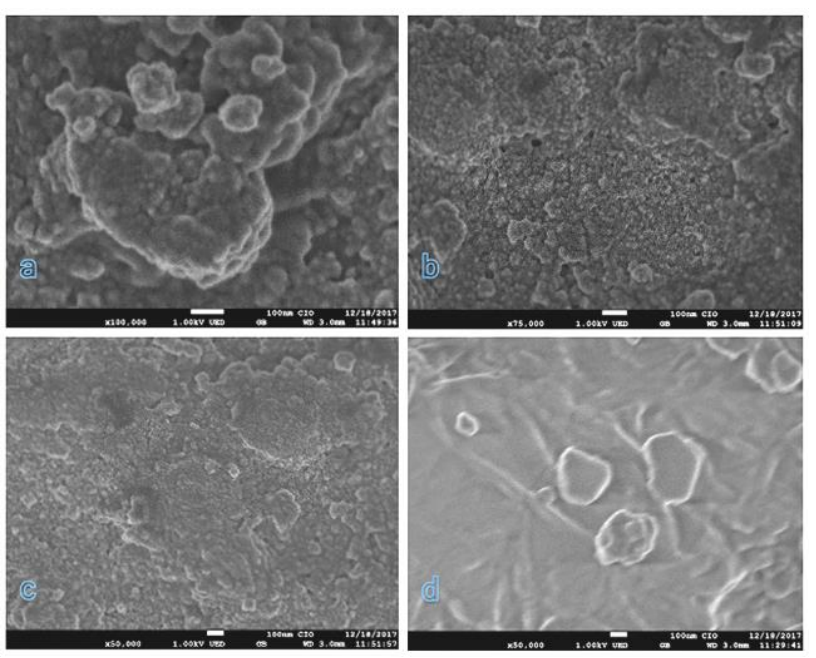

Figure 1 SEM micrographs of $\mathrm{ZnO}$ nanoparticles Source: own work [JEOL SU 3500 SEM Hitachi]

Graphic 8 shows the impedance spectrum corresponding to the films made with prepared solutions of $0.1 \%, 0.3 \%$ and $0.5 \% \mathrm{w} / \mathrm{w}$ $\mathrm{ZnO}$ in methanol. It is observed that as the concentration increases the resistance of the film decreases. The same trend is followed in Graphic 9 which corresponds to the spectrum of films made with solutions of $\mathrm{ZnO}$ AL 1\%, 3\% and 5\% $\mathrm{w} / \mathrm{w}$, in methanol. This corroborates the semiconductor capacity of the material, the higher the concentration, the better the conductivity.

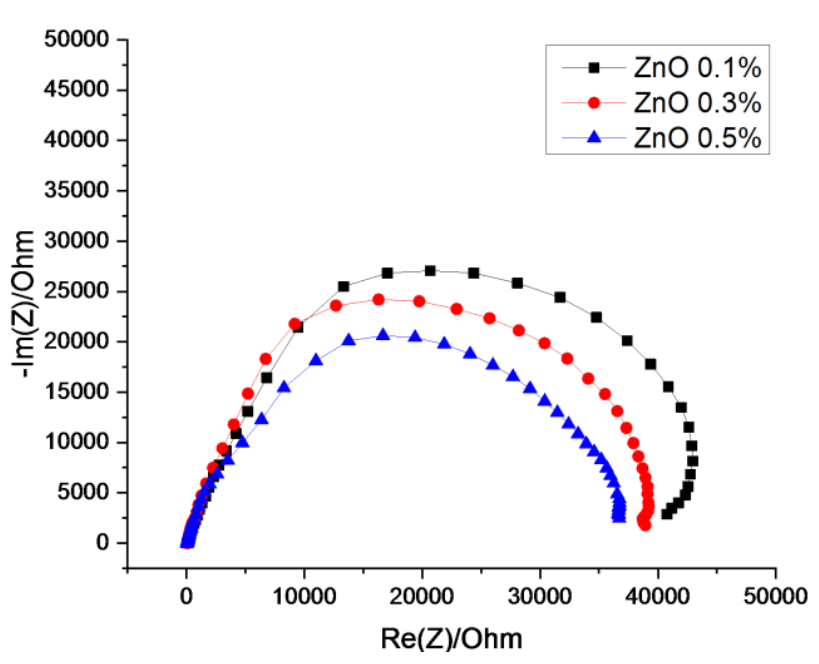

Graphic 8 Electrochemical Impedance Spectrum of $\mathrm{ZnO}$ particles at concentrations $0.1 \%, 0.3 \%, 0.5 \%$ in methanol Source: own work [OriginPro 9]

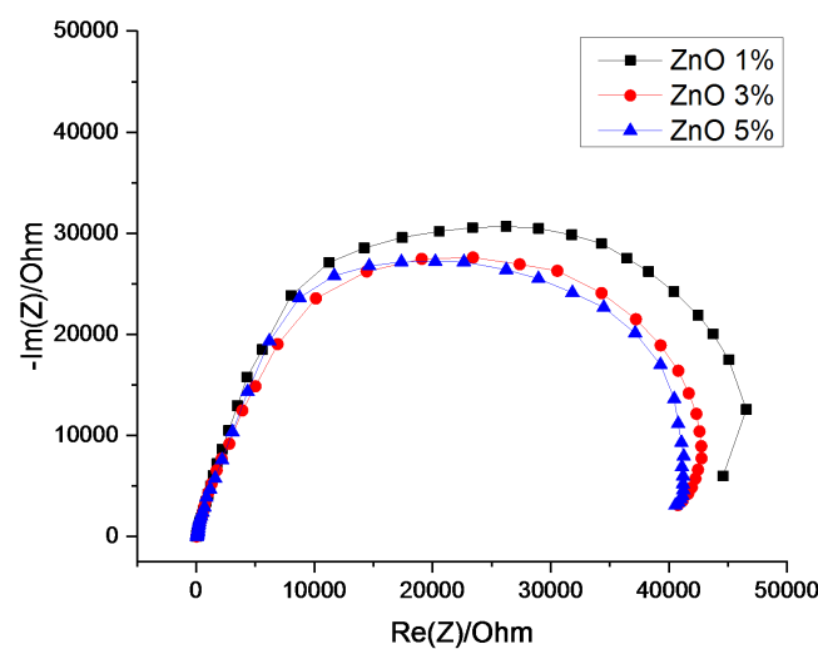

Graphic 9 Electrochemical Impedance Spectrum of $\mathrm{ZnO}$ particles at concentrations $1 \%, 3 \%, 5 \%$ in methanol Source: own work [OriginPro 9]

Graphics 10, 11, 12 and 13 describe the chronoamperogram of the film formed with $0.3 \%, 1 \%, 3 \%$ y $5 \% \mathrm{w} / \mathrm{w} \mathrm{ZnO}$ in methanol, it is observed that at a higher concentration of $\mathrm{ZnO}$ the amount of UV light it absorbs is less. This is because the $\mathrm{ZnO}$ disperses the incident radiation on the film. It is also observed that when the concentration of the nanomaterial is increased, the absorption intensity remains constant, which encourages believing that it can be irradiated with UV light for long periods.

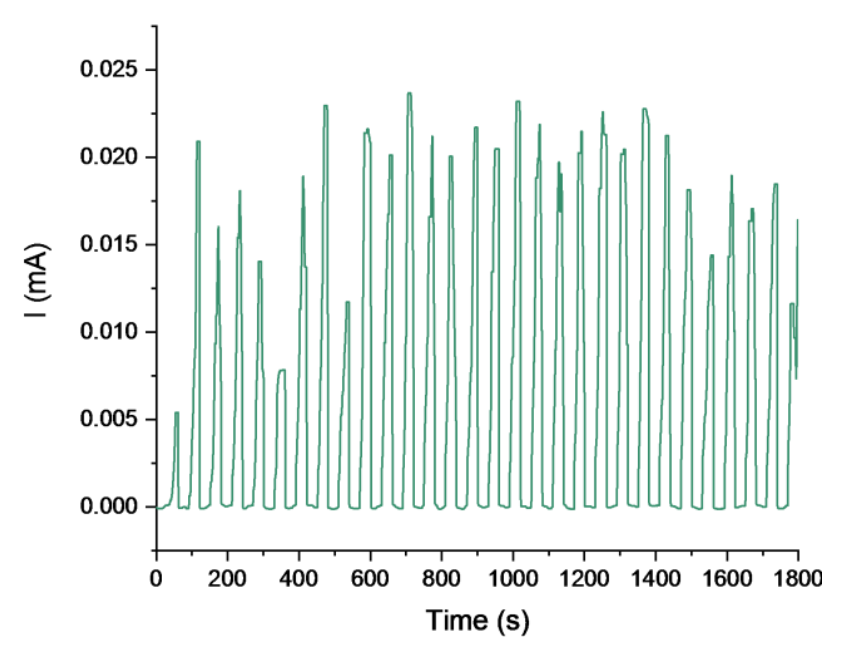

Graphic 10 Chronoamperogram of a $0.3 \%$ w/w $\mathrm{ZnO}$ film in methanol

Source: own work [OriginPro 9] 


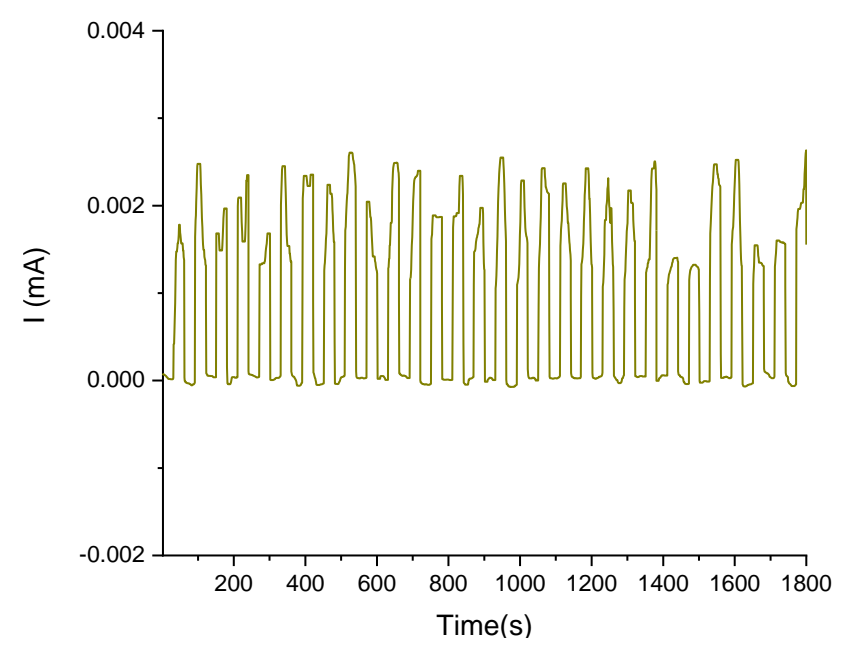

Graphic 11 Chronoamperogram of a $1 \% \mathrm{w} / \mathrm{w} \mathrm{ZnO}$ film in methanol

Source: own work [OriginPro 9]

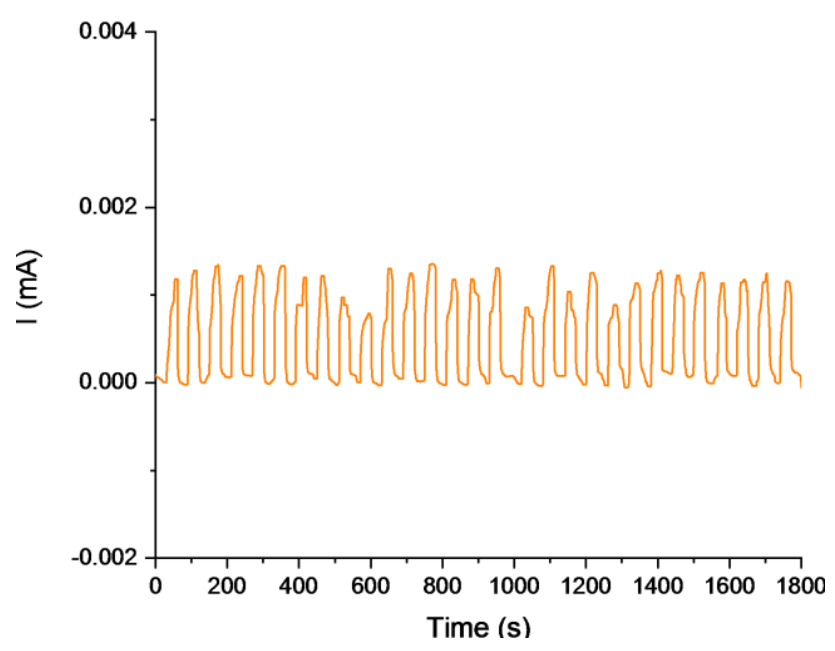

Graphic 12 Chronoamperogram of a 3\% w/w $\mathrm{ZnO}$ film in methanol

Source: own work [OriginPro 9]

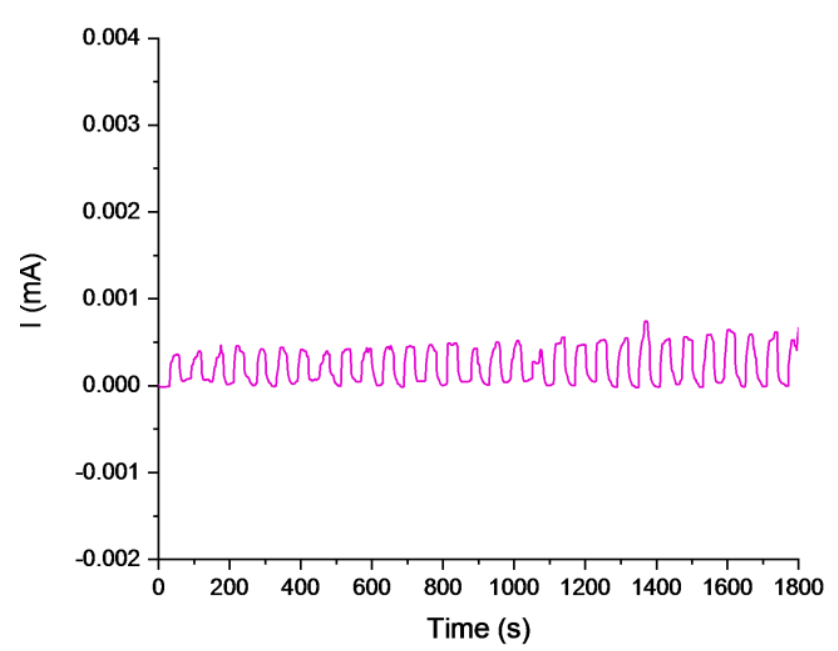

Graphic 13 Chronoamperogram of a 5\% w/w ZnO film in methanol

Source: Own work [OriginPro 9]

It was decided to use monoethylene glycol as a dispersing phase for the $\mathrm{ZnO}$ nanoparticles, due to the non-formation of agglomerates in the films applied on the substrates, as shown in Figure 2.

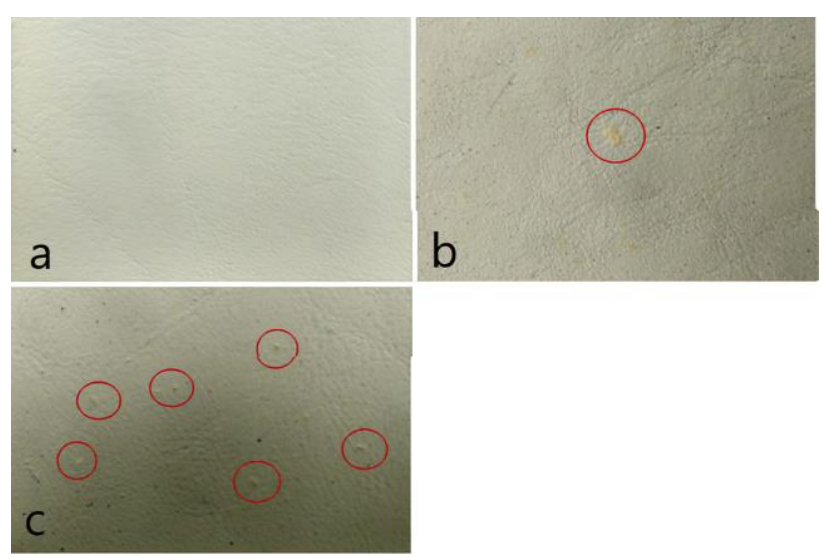

Figure 2 Application of the first coating layer with nanoparticles dispersed in a) Monoethylene glycol, b) Polyethylene glycol, c) Ethanol-water mixture Source: own work [Microsoft Office Word]

The samples applied to leather finishing were exposed to solar radiation for 70 days, and it was considered an unexposed reference sample. The evaluation of this samples was with a colorimeter, colour difference $\left(\Delta \mathrm{E}^{*}\right)$, as show in Table 1.

\begin{tabular}{|c|c|c|c|c|c|}
\hline $\begin{array}{l}\text { Number of layers } \\
\text { applied on the } \\
\text { substrate }\end{array}$ & 1 & 2 & 3 & 4 & 5 \\
\hline $\begin{array}{c}\text { Colorimetric } \\
\text { parameter } \\
\text { evaluation, b* }\end{array}$ & $\begin{array}{l}\Delta \mathrm{b}: \\
9.52\end{array}$ & $\begin{array}{l}\Delta \mathrm{b}: \\
8.38\end{array}$ & $\begin{array}{l}\Delta \mathrm{b}: \\
6.26\end{array}$ & $\begin{array}{l}\Delta \mathrm{b}: \\
3.04\end{array}$ & $\begin{array}{l}\Delta \mathrm{b}: \\
2.69\end{array}$ \\
\hline
\end{tabular}

Table 1 Application of films, with $\mathrm{ZnO}$ nanoparticles synthesized via $\mathrm{pH} 9$ sol-gel, in leather substrate, dispersed in monoethylene glycol

Source: own work [VHX-7000 Series Digital Microscope]

\section{Conclusions}

The sol-gel method represents a simple synthesis method with low cost and high productivity $\mathrm{ZnO}$. UV-Vis spectroscopy with diffuse reflectance and chronoamperometries confirmed the good absorption of UV radiation from the synthesized $\mathrm{ZnO}$. The sample irradiated by sunlight that contained $\mathrm{ZnO}$ nanoparticles in the leather finish was preserved in a better state than the one that did not contain nanoparticles. The addition of $\mathrm{ZnO}$ nanoparticles to the leather finish layers greatly improved their mechanical properties and thermal stability. The $\Delta \mathrm{b}$ value was reduced by $74 \%$, a value of 2.69 was obtained for this parameter, which is only 0.69 units above the maximum allowed value $(\Delta \mathrm{b}: 2)$.

AGUILAR-MARURI, Saul, VALENCIA-RODRÍGUEZ, Samantha, GALINDO-GONZÁLEZ, Rosario and FUENTES-RAMÍREZ, Rosalba. Development of a coating with UV protection for leather finishing in the automobile industry. Journal of Scientific and Technical Applications. 2020 


\section{Acknowledgments}

This project was conducted under the results from project IJ - 236 -2019.

To "Centro de Investigaciones en Óptica, A.C." for the contribution with SEM micrographs of $\mathrm{ZnO}$ nanoparticles.

\section{References}

A. J. Bailey, N. D. (1980). "Chemical crosslinking restrictions on models for the molecular organization of the collagen fibre,". Nature, vol. 288, no. 5789, pp. 408-410.

A. K. Zak, M. E. (2011). "Effects of annealing temperature on some structural and optical properties of $\mathrm{ZnO}$ nanoparticles prepared by a modified sol - gel combustion method". Ceramics International, vol. 37, pp. 393-398.

al., H. Z. (2002). "Behind the weak excitonic emission of $\mathrm{ZnO}$ quantum dots: $\mathrm{ZnO} / \mathrm{Zn}(\mathrm{OH}) 2$ core-shell structure". Appl. Phys. Lett., vol. 80, no. 2, pp. 210-212.

al., L. L. (2018). "Photocatalytic properties of Fe-doped $\mathrm{ZnO}$ electrospun nanofibers". Ceram. Int.

C. A. Arguello, D. L. (1969). "First-Order Raman Effect in Wurtzite-Type Crystals". Phys. Rev., vol. 181, no. 3, pp. 1351-1363.

C. Niculescu, O. L. (2012). "Characterization of coating aqueous disperse systems used in natural leather finishing". Chem. Mag. Bucharest, vol. 63, no. 9, pp. 900-905.

D. Sun, M. W. (2007). "Purification and stabilization of colloidal $\mathrm{ZnO}$ nanoparticles in methanol" . J. Sol-Gel Sci. Technol., vol. 43, no. 2, pp. 237-243.

Golzary, M. K. (2014). "Spectrochimica Acta Part A: Molecular and Biomolecular Spectroscopy Synthesis of zinc oxide nanoparticles - chitosan for extraction of methyl orange from water samples: Cuckoo optimization algorithm - artificial neural network". Spectrochim. ACTA PART A Mol. Biomol. Spectrosc., vol. 131, pp. 189-194.
J. F. De Lima, R. F. (2012). “Transparent UVabsorbers thin films of zinc oxide : Ceria system synthesized via sol - gel process". Opt. Mater. (Amst)., vol. 35, no. 1, pp. 56-60.

L. Li, J. D. (2010). "Synthesis and characterization of chitosan / $\mathrm{ZnO}$ nanoparticle composite membranes". Carbohydr. Res., vol. 345, no. 8, pp. 994-998.

L. Wallenhorst, L. G. (2018). “Applied Surface Science UV-blocking properties of $\mathrm{Zn} / \mathrm{ZnO}$ coatings on wood deposited by cold plasma spraying at atmospheric pressure". Applied Surface Science, vol. 434, pp. 1183-1192.

M. Shaban, S. A. (2016). "Characterization and photocatalytic properties of cotton fibers modified with $\mathrm{ZnO}$ nanoparticles using sol - gel spin coating technique" . Beni-Suef University Journal of Basic and Applied Sciences, vol. 5, pp. 277-283.

P. Kumar, S. S. (2018). "Investigations on optical properties of $\mathrm{ZnO}$ decorated graphene oxide ( $\mathrm{ZnO} @ \mathrm{GO})$ and reduced graphene oxide (ZnO@r-GO)". J. Alloys Compd., vol. 744, pp. 64-74.

Pavel, T. G. (2011). "Titanium dioxide and zinc oxide nanoparticles in sunscreens: Focus on their safety and effectiveness". Nanotechnol. Sci. Appl., vol. 4, no. 1, pp. 95-112.

Prasad, A.\&. (2018). Effective photocatalytic removal of different dye stuffs using green synthesized zinc oxide nanogranules. Materials Research Bulletin, vol. 102, no. Feb, pp. 116121.

S. Jurablu, M. F. (2015). "Sol-Gel Synthesis of Zinc Oxide ( $\mathrm{ZnO}$ ) Nanoparticles: Study of Structural and Optical Properties". Journal of Sciences, Islamic Republic of Iran, University of Tehran, vol. 26, no. 3, pp. 281-285.

Soto-Robles, C. \&.-N.-B. (2017). "Fruit peel extract mediated green synthesis of zinc oxide nanoparticles" . Journal of Molecular Structure, vol. 1147, pp. 1-6. 
Thambidurai, M. K. (2017). "Chitosan/zinc oxide-polyvinylpyrrolidone (CS/ZnO-PVP) nanocomposite for better thermal and antibacterial activity". International journal of biological macromolecules, Volume 104, Part B, Pages 1753-1761.

Valencia-Rodríguez, S. (Septiembre de 2018). "Desarrollo del recubrimiento para protección a los rayos UV del acabado del cuero para la industria automotriz". Tesis. Guanajuato, Guanajuato, México.

W. A. G. Bruls, H. S. (1984). "TRANSMISSION OF HUMAN EPIDERMIS AND STRATUM CORNEUM AS A FUNCTION OF THICKNESS IN THE ULTRAVIOLET AND VISIBLE WAVELENGTHS". Photochem. Photobiol., vol. 40, no. 4, pp. 485-494. . 